İşletme Akademisi Dergisi
2020, (3): 174-186
DOI:10.2677/TR 1010.2020 .540
Dergi web sayfasi: www.isakder.org

Derleme Makalesi

\title{
Anonim Şirketlerde Kar Payı Dağıtımı ve Yeni Koronavirüs (Covid-19) Salgın Döneminin Kar Payı Dağıtımı Üzerine Etkileri
}

\author{
Dr. Öğretim Üyesi Efe DÜNDAR \\ Muğla Sıtkı Koçman Üniversitesi, İktisadi ve İdari Bilimler Fakültesi, İşletme Bölümü, Ticaret \\ Hukuku ABD, Muğla \\ efedundar@mu.edu.tr https://orcid.org/0000-0002-1174-7527
}

\section{Prof. Dr. Tuğba UÇMA UYSAL}

Muğla Sıtkı Koçman Üniversitesi, İktisadi ve İdari Bilimler Fakültesi, Uluslararası Ticaret ve Finansman Bölümü, Uluslararası İşletmecilik ABD, Muğla

ucmatugba@gmail.com https://orcid.org/0000-0002-3652-7221

\section{Öz}

Bir ekonomik birimin faaliyet sonucu olarak ifade edilen karın dağıtımı, işletmenin alacağı önemli stratejik kararlardan birini oluşturmaktadır. Kar dağıtımında en önemli noktayı net karın dağıtılacak olan kısmının belirlenmesinde işletmeye ait tüm paydaşların çıkarları gözetilerek bir kar dağıtım stratejisinin benimsenmesi oluşturmaktadır. Bu noktada ülkeler seviyesindeki yasal mevzuatlar işletmelerde benimsenen kar dağıtım süreçlerine doğrudan etkiler yapmaktadır. Karın dağıtımına yönelik hazırlanan yasal altyapının özellikle finansal kriz veya içinde bulunduğumuz yeni Koronavirüs (Covid 19) salgın süreci gibi ekonomik etkiler başta olmak üzere birden fazla boyutta etkileri olan kriz dönemlerinde ve sonrasında nasıl olması gerektiği ise önemli bir sorun olarak karşımıza çıkmaktadır. Yeni Koronavirüs salgın dönemindeki belirsizlik ortamının şirketler üzerindeki olası etkilerini azaltmak amacıyla ülkemizde de karın dağıtımına yönelik bir yasal düzenleme yapılmıştır.Bu çalışmada öncelikle sermaye şirketlerindeki kar payı hakkı ve kar payı dağıtımına ilişkin yasal mevzuat üzerinde durulmakta ardından özellikle salgın sürecinde bu salgının ekonomik ve sosyal hayata olan etkilerini azaltmak amacıyla 6102 Sayılı Türk Ticaret Kanunu'na eklenen geçici 13. Madde ile net dönem karının dağıtımının usul ve esaslarının değerlendirilmesi ve yeni belirlenen usul ve esasların uygulanma süreçleri hakkında açıklamalara yer verilmektedir.

Anahtar Kelimeler: Anonim Şirketler, Kar Payı Dağıtımı, Koranavirüs Salgının Etkileri

Makale Gönderme Tarihi: 07.07.2020

Makale Kabul Tarihi: 15.08 .2020

\section{Önerilen Atıf:}

Dündar, E. ve Uçma Uysal, T., (2020). Anonim Şirketlerde Kar Payı Dağıtımı ve Yeni Koronavirüs (Covid-19) Salgın Döneminin Kar Payı Dağıtımı Üzerine Etkileri, İşletme Akademisi Dergisi, 1(3): 174-186.

(C) 2020 İşletme Akademisi Dergisi. 


Journal of Business Academy
2020,1 (3): 174-186
DOI:10.26677/TR1010.2020.540
Web pages: www.isakder.org

$\underline{\underline{\text { Review }}}$

\title{
Profit Share Distribution in theJointStockCompaniesand The Effects of New Coronavirus (Covid 19) PandemicEra on Profit Share Distribution
}

\section{Dr. Efe DÜNDAR}

Muğla Sıtkı Koçman University, Faculty of Economics and Administration Sciences, Department of Business Management,

efedundar@mu.edu.tr https://orcid.org/0000-0002-1174-7527

\section{Prof. Dr. Tuğba UÇMA UYSAL}

Muğla Sıtkı Koçman University, Faculty of Economics and Administration Sciences, Department of International Trade and Finance, ucmatugba@gmail.com https://orcid.org/0000-0002-3652-7221

\begin{abstract}
Profit distribution, which is expressed as the result of the activity of an economic unit, is one of the important strategic decisions to be taken by the companies. The most important point in profit share distribution is the adoption of a profit distribution strategy by considering the interests of all stakeholders of the company in determining the part of the net profit to be distributed. In this context, the legal regulations at the country level have direct effects on the profit distribution processes adopted in the enterprises. How the legal infrastructure prepared for the distribution of the profit should be during and after the crisis with multiple effects, especially the financial crisis or the new Coronavirus (Covid 19) epidemic process, is an important problem. In order to reduce the possible effects of the uncertainty environment on the companies during the new coronavirus pandemic era, the legal regulation has been made for the distribution of profit in our country. This study primarily focuses on dividend rights and profit share distribution in companies. Then, via the provisional Article 13- which added to the Turkish Commercial Code No. 6102 in order to reduce the effects of this epidemic on economic and social life, especially during the epidemic process- the procedures and principles of the net profit distribution were evaluated and explanations about the implementation processes of the newly determined procedures and principles are included.
\end{abstract}

Keywords: Joint Stock Companies, Profit Share Distribution, The Effects of New Coronavirus Pandemic

Received: 07.07.2020

Accepted: 15.08 .2020

Suggested Citation:

Dündar, E. ve Uçma Uysal, T., (2020). Profit Share Distribution in the Joint Stock Companies and The Effects of New Coronavirus (Covid 19) Pandemic Era on Profit Share Distribution, Journal of Business Academy, 1(3): 174-186.

(C) 2020 Journal of Business Academy. 


\section{GİRIŞ: Muhasebe Teorisi ve Kar Dağıtımı Olgusu}

Genel anlamda muhasebe teorisi, muhasebe ilkelerinin birer açılaması niteliğinde ortaya çımakta ve uygulamalara yön vermekte olup, kavramsal ve pragmatik ilkelerin bütününü kapsamaktadır (Hendriksen, 1982: 1). Bu ilkelerin oluşumunda, pratikler ve prosedürler yer almakta olup, tarihsel perspektif içerisinde gelişen ekonominin merkezinde şekillenmektedir. Bu anlamda muhasebe teorisi, muhasebenin kurallarını uygulamalara rehber olacak nitelikte açılayan ve amacı, muhasebe ilkeleri ile altı çizilen temel kavramları ve fikirleri nasıl uygulama süreçleri ile birleştirileceğini gösteren bir teori olarak karşımıza çıkmaktadır. Bu temel kavramların bilgisi, muhasebe problemlerinin çözümünde ve değişen koşullara bağlı olarak ihtiyaç duyulan yeni ilkelerin gelişiminde kullanılmaktadır. Bu doğrultuda muhasebe ilkeleri iş yapma düşüncesi ve faaliyetleri içerisinde yaygın olan görüş ve fikirler etrafında şekillenmekte ve bu ilkelerin bütününden oluşan muhasebe teorisi, bu inanışları yansıtmaktadır (Littleton ve Zimmerman, 1962: 135). Uygulamalara yön veren ve uygulama sonuçlarının işletmenin finansal verilerine dönüşmesine yol gösteren muhasebe teorisi, işletmenin finansal verilerinin analizi ve bu verilerin karar alım süreçlerinde kullanılmasına da katkı yapmaktadır.

$\mathrm{Bu}$ bağlamda işletmede üretilen finansal tablolar belirleyici bir nitelik taşımaktadır. Türkiye Muhasebe Standardı (TMS) 1 - Finansal Tabloların Sunuluşuna göre finansal tablolar, işletmenin finansal durumunun ve finansal performansının biçimlendirilmiş sunumu şeklinde ortaya çıkmaktadır. Bir anlamda işletmenin finansal dili olarak tanımlanan finansal tabloların genel amacı da işletmenin finansal durumu, finansal performansı ve nakit akışları hakkında geniş bir kullanıcı kitlesine ekonomik kararlar alırken faydalı olacak bilgiyi sağlamaktır. Bununla birlikte finansal tablolar işletmede yönetime yatırımlar aracılığı ile emanet edilen kaynakların nasıl kullanıldığının sonuçlarını göstermek açısından da son derece önem taşımaktadır. Bu bağlamda işletme içindeki ve dışındaki bilgi kullanıcıların karar alım süreçlerine temel oluşturan en önemli konuların başında ise kar ve kar dağıtımının geldiği söylenebilir. En genel ifade ile kâr, bir ekonomik biriminin faaliyetlerini ölçmek amacıyla kullanılan en önemli göstergelerden biri olarak karşımıza çıkmaktadır. İşletmenin bir faaliyet dönemi içerisindeki faaliyet sonuçlarının karşılığı olarak değerlendirilmekte ve karar alıcıların da sıklıkla başvurduğu temel gösterge olmaktadır. Bu anlamıyla bir ekonomik birimdeki faaliyet sonucunda oluşan karın yönetilmesi de yine işletmenin alacağı önemli stratejik kararlardan birini oluşturmaktadır. Bu noktada işletme yönetiminin işletmenin iç ve dış çevresindeki bilgi kullanıcılarının da ihtiyaçlarına cevap verebilecek nitelikte geçmiş dönemlere ait faaliyetlerinin analizini ve yorumlamasını sağladıktan sonra yine belirtilen karar alıcılar açısından temel bir gösterge olarak kabul edilen net karın dağıtımına karar vermesi gerekmektedir.

Bununla birlikte TMS 1 içerisindeki temel finansal tablolardan biri olan kâr veya zarar ve diğer kapsamlı gelir tablosu bilgi kullanıcılarının bu temel ihtiyacına cevap verecek nitelikte bilgiyi sunmaktadır. Bu anlamıyla da kar veya zarar diğer kapsamlı gelirin bileşenleri dâhil edilmeden, toplam gelirden giderler düşüldükten sonra kalan tutarı ifade etmek amacıyla kullanılmaktadır. Bu nedenle işletmedeki net kar ve net karın dağıtımının nasıl olacağı sorusu muhasebe ve finans disiplini içerisinde önemli bir yer bulduğu gibi (Shabani vd., 2014: 3103), kar ve dağıtımı teorisi yaygın makro dinamik modeller içerisinde de gösterilmektedir (Pasinetti, 1962).

Kar dağıtımında en önemli noktayı net karın dağıtılacak olan kısmının belirlenmesi ve tüm ortakların çıkarları doğrultusunda bir kar dağıtım stratejisinin gözetilmesi oluşturmaktadır (Petrova ve Beztsenny, 2016). Uygulamada kârın dağıtımına ilişkin kararlar, kısmen veya tamamen hissedarların çıkarları gözetilerek alınmaktadır. Ancak ülkeler seviyesindeki yürürlükte olan yasal mevzuatlar da sürecin işletmeler açısından hem raporlanması hem de dağıtılmasına ilişkin usul ve esasları belirlemesi açısından düzenlemeler yapmaktadır. Bu da 
işletmeler seviyesinde gerçekleşen ve karar alımında önemli bir yer tutan kar payı dağıtımına ilişkin finansal bilginin hangi miktarlarda dağıtılacağını ve nasıl raporlanacağını belirlemektedir.

Karın dağıtımına yönelik hazırlanan yasal altyapının özellikle finansal kriz veya içinde bulunduğumuz yeni Koronavirüs (Covid 19) salgın süreci gibi ekonomik etkiler başta olmak üzere birden fazla boyutta etkileri olan kriz dönemlerinde ve sonrasında nasıl olması gerektiği tüm dünyada yeniden şekillendirilmektedir. Bu çalışmada öncelikle sermaye şirketlerindeki kar payı hakkı ve kar payı dağıtımına ilişkin yasal mevzuat üzerinde durulmakta ardından özellikle salgın sürecinde bu salgının ekonomik ve sosyal hayata olan etkilerini azaltmak amacıyla 6102 Sayılı Türk Ticaret Kanunu'na eklenen geçici 13. Madde ile net dönem kar dağıtımının usul ve esaslarının değerlendirilmesi ve yeni belirlenen usul ve esasların uygulanma süreçleri hakkında açıklamalara yer verilmektedir.

\section{KAR PAYI HAKKI}

Türk Ticaret Kanunu'nun (TTK) 507/1 uyarınca her pay sahibi kanun ve esas sözleşme hükümlerine göre pay sahiplerine dağıtılması kararlaştırılmış net dönem kârına, payı oranında katılma hakkını sahiptir. Kâr payı hakkı mevzuatta iki ayrı anlamda ele alınmıştır. Bu anlamlardan ilki kâr payı hakkının pay sahipleri bakımından vazgeçilemez hak olması (Pulaşlı, 2020: 568) ikincisi ise mal varlıksal hak niteliği kapsamında pay sahibinin kanun ve esas sözleşme hükümlerine veya genel kurul kararları sonucunda ortaya çıkan dağıtılmaya tahsis edilen yıllık kâra veya dağıtılmaya tahsis olunan yedek akçelere katılması ile gerçekleşen haktır (Poroy vd., 2019: 696). Bununla birlikte TTK'nın 408. maddesine gör kâr payının dağıtılıp dağıtılamayacağı ve bu hususa mukabil olarak miktarı konusunda yetkinin genel kurula ait olduğu da açılanmaktadır.

İlk olarak kâr payı hakkının dağıtım yetkisi genel kurulun devredilmez yetki ve görevleri arasında sayılmaktadır. TTK'nın 408. Maddesinin 1. Fikrasında yer alan "Genel kurul, kanunda ve esas sözleşmede açıkça öngörü̈lmüş bulunan hâllerde karar alır." ifadesinde genel kurulun karar verme yetkisini kanundan ve kanun hükümleri çerçevesinde düzenlenmiş bulunan esas sözleşmeden alabileceğine hükmedilmiştir. Bu hüküm aynı zamanda genel kurul ile yönetim kurulu arasında görev ve yetki paylaşımındaki sınırı da çizmektedir (Poroy vd.,2019: 531). Benzer nitelikte TTK'nın 408. maddesinin 2. fikrasında ise genel kurulun devredilemez görev ve yetkileri sayılmıştır. Bu görev ve yetkiler şunlardır:

(1) Genel kurul, kanunda ve esas sözleşmede açıçca öngörülmüş bulunan hâllerde karar alır.

(2) Çeşitli hükümlerde öngörülmüş bulunan devredilemez görevler ve yetkiler saklı kalmak üzere, genel kurula ait aşağıdaki görevler ve yetkiler devredilemez:

a) Esas sözleşmenin değiştirilmesi.

b) Yönetim Kurulu üyelerinin seçimi, süreleri, ücretleri ile huzur hakk1, ikramiye ve prim gibi haklarının belirlenmesi, ibraları hakkında karar verilmesi ve görevden alınmaları.

c) (Değişik: 26.6.2012-6335/22 md.) Kanunda öngörülen istisnalar dışında denetçinin seçimi ile görevden alınması.

d) Finansal tablolara, yönetim kurulunun yıllık raporuna, yillık kâr üzerinde tasarrufa, kâr payları ile kazanç paylarının belirlenmesine, yedek akçenin sermayeye veya dağıtılacak kâra katılması dâhil, kullanılmasına dair kararlarnn alınması.

e) Kanunda öngörülen istisnalar dışında şirketin feshi.

f) Önemli miktarda şirket varlı̆̆ının toptan satışı. 
(3) Tek pay sahipli anonim şirketlerde bu pay sahibi genel kurulun tüm yetkilerine sahiptir. Tek pay sahibinin genel kurul sıfatıyla alacağı kararların geçerlilik kazanabilmeleri için yazılı olmaları şarttır.

Görüldüğü üzere kâr payının belirlenmesi ve sonraki süreç içerisinde kâr payının dağıtılmasına dair mutlak yetkili organ anonim şirket genel kuruludur. Ancak yetki her ne kadar genel kurulda olsa da dağıtımın gerçekleştirilmesi ve miktarın tespiti hususlarında genel kurul esas sözleşme ile bağlıdır (Bahtiyar, 2020, s. 299). Kar payı hakkına ilişkin yapılan açıklamalar ile birlikte hakkın dağıtımına yönelik uyulacak usul ve esaslar TTK'da ayrıca düzenlenmiş bulunmaktadır.

\section{KAR PAYI HAKKININ DAĞITIMI VE KAR PAYI DAĞITIMINA İLIŞKİN GENEL KURUL KARARLARININ İPTALİ VE BUTLANI}

Belirtilen durum içerisinde anonim şirketlerde TTK'ya göre kâr payı dağıtılmasının şartları ise aşağıdaki gibi ifade edilmektedir:

(1) TTK 509/1 uyarınca kâr payı ancak net dönem kârından ve serbest yedek akçelerden dağıtılabilir.

(2) Yıllık bilançoya göre kâr elde edilmiş olmalı veya önceki yılların kârlarından bu amaç dâhilinde kullanılabilmesi mümkün yedek akçe ayrılmış olmalıdır (Bahtiyar, 2020: 299; Pulaşlı, 2020: 568). Bu durum itibariyle anonim şirketler kâr etmediği takdirde kâr payının dağıtımı mümkün değildir (Kayıhan, 2019: 274).

(3) Pay sahiplerine dağıtılacak kâr payının belirlenebilmesi için kanuni ${ }^{1}$ ve esas sözleşmede öngörülen isteğe bağlı yedek akçeler² ayrılmalıdır(TTK 523/1).

(4) Kâr payının dağıtılabilmesi için 2. ve 3. maddede sayılan ilgili kalemler net dönem kârından ayrılmalıdır (Pulaşli, 2020: 568).

(5) Kâr payının nakden ödenmesi gerekli olup ilgili pay TTK 508/1 uyarınca esas sözleşmede aksine hüküm yok ise kâr ve tasfiye payı pay sahibinin sermaye payı için şirkete yaptığı ödemelerle orantılı olarak hesap edilmelidir. TTK 507/2 ise kâr payı konusunda bir istisnai düzenleme olup esas sözleşme de bu yönde bir hüküm bulunması halinde pay sahiplerinin kâra eşit oranda katılımını ön gören genel ilkenin istisnasını oluşturur.

(6) Kâr dağıtım kararı bir genel kurul karar olup bu kararın alınabilmesi için her şeyden önce TTK 519/1'e göre yıllık kârın yüzde beşi, ödenmiş sermayenin yüzde yirmisine ulaşıncaya

\footnotetext{
${ }^{1}$ Kanun gereği ayrılması zorunlu yedek akçe kaynağını TTK 519'dan alır. Bu hususa göre yıllık karın yüzde beşi ödenmiş sermayenin yüzde 20 sine ulaşıncaya kadar genel kanuni yedek akçe ayrılması zorunlu olup, bu zorunlu sınır koşul olarak sağlandıktan sonra 519/2 uyarınca" a) Yeni payların çıkarılması dolayısıyla sağlanan primin, çıkarılma giderleri, itfa karşlıkları ve hayır amaçlı ödemeler için kullanılmamış bulunan kısmı, b) Iskat sebebiyle iptal edilen pay senetlerinin bedeli için ödenmiş olan tutardan, bunların yerine verilecek yeni senetlerin çıkarılma giderlerinin düşülmesinden sonra kalan kısmı, c) Pay sahiplerine yüzde beş oranında kâr payı ödendikten sonra, kârdan pay alacak kişilere dağıtılacak toplam tutarın yüzde onu, genel kanuni yedek akçeye eklenir". Genel kanuni yedek olarak tanımlanan bu hal kapsamında; sermayenin veya çıkarılmış sermayenin yarısını aşmadığı takdirde, sadece zararların kapatılmasına, işlerin iyi gitmediği zamanlarda işletmeyi devam ettirmeye veya işsizliğin önüne geçmeye ve sonuçlarını hafifletmeye elverişli önlemler alınması için kullanılabilir. (519/3)

2 Bu yedek akçeler kanuni yedek akçenin dışındaki yedek akçelerdir. 2'ye ayrılır: 1. Ana sözleşme ile ayrılan yedek akçe;TTK'nın 521. maddesi kapsamında ana sözleşmeye konulacak olan bir hüküm olup konusunu yıllık karın yüzde beşinden fazla bir tutarın yedek akçe olarak ayrılabileceği veya yedek akçenin ödenmiş sermayenin yüzde yirmisinin aşılabileceğinin değerlendirilerek ve bunların özgülenme amacıyla harcanma yolları ve şartları belirlenebilmesidir. 2. Genel kurul kararıyla ayrılan yedek akçe; TTK 523. maddesi kapsamında; "Genel kurul; a) Aktiflerin yeniden sağlanabilmesi için gerekliyse, b) Bütün pay sahiplerinin menfaatleri dikkate alındığında, şirketin sürekli gelişimi ve olabildiğince kararlı kâr payı dağıtımı yönünden haklı görülüyorsa, Kanunda ve esas sözleşmede öngörülenlerden başka yedek akçe ayrılmasına da karar verebilir." Bu koşulun gerçekleşebilmesi için Kanuni ve esas sözleşmede öngörülen isteğe bağlı yedek akçeler ayrılmış olmalıdır.
} 
kadar genel kanuni yedek akçeye ayrılmalıdır. Bu husus tamamlanmış ise TTK'nın 409. Maddesi hükmünce toplantılar usulünce gerçekleştirilmelidir. Şayet yedek akçeye yıllık kârın yüzde beşinden fazla bir tutarın ayrılacağı ve yedek akçenin ödenmiş sermayenin yüzde yirmisini aşabileceği hakkında esas sözleşmeye hüküm konulmuş ise bu duruma ayrıca genel kurul tarafından uyulmalıdır(TTK 521/1).

(7) Kar payı dağıtımına ilişkin genel kurul toplantıları aksi sözleşme ile ön görülmemişse TTK'nın 418.maddesi kapsamında sermayenin en az dörtte birini karşılayan payların sahiplerinin veya temsilcilerinin varlığıyla toplantı icra edilmelidir ve bu nisabın toplantı süresince korunması şarttır. İlk toplantıda anılan nisaba ulaşılamadığı takdirde, ikinci toplantının yapılabilmesi için nisap aranmayacaktır. Genel kurul tarafından kâr dağıtım kararının verilmesi ve miktarın saptanması kararları ise her halde toplantıda hazır bulunan oyların çoğunluğu ile verilmelidir.

Yapılan açıklamalar doğrultusunda TTK'da kar payı hakkının dağıtım yetkisi ve şartları hakkında detaylı açıklamalar yer aldığı görülmektedir. Bunlara ek olarak özellikle uygulama noktasında yaşanabilecek sorunlar da göz önüne alınarak TTK'da genel kurul kararlarının iptali ve butlanı konusu da düzenlenmiştir. İlgili hükümler kapsamında genel olarak uygulamada karşılaşılan somut olayın varlığına göre kâr payı dağıtımına ilişkin alınan genel kurul kararlarının iptali ve butlanı söz konusu olabilir. TTK'nın445. Maddesinde genel kurul kararının iptal sebepleri düzenlenmiş olup TTK'nın 447. maddesinde ise hangi koşul ve hallerde genel kurulda alınan kararların butlan sayılacağı düzenlenmiştir. 448. madde ile 451. maddeleri arasında ise iptal ve butlan davasını konu edinen ortak hükümler düzenlenmiştir. Örneğin TTK'nın 450. maddesine göre Genel kurul kararının iptaline veya butlanına ilişkin mahkeme kararı, kesinleştikten sonra bütün pay sahipleri hakkında hüküm ifade etmektedir.

Hukukî sonuç doğuran bir irade beyanı olması nedeniyle genel kurul kararı, bir hukukî işlem niteliğindedir. Genel kurul kararlarının iptale tabi olması için kararın toplantı ve karar nisaplarına uygun olarak alınmış şeklen geçerlilik unsurlarını taşıyan; ancak konusu bakımından, kanuna, esas sözleşmeye ve/veya özellikle dürüstlük kurallarına aykırı olması gerekir. İptal davası açabilmek için ise pay sahiplerinin veya şirketin herhangi bir zarar görmüş olması şart değildir (Moroğlu, 2014: 303-305) Genel kurul kararlarının iptalinin söz konusu olabilmesi için Yargıtay ${ }^{3^{\prime}}$ da ilk şart olarak alınmış geçerli bir kararın varlığını aramaktadır.

Bunlara ek olarak TTK'nın 445. maddesinde genel kurul kararının iptal sebepleri düzenlenmiştir. Genel kurul kararlarının başta yasal mevzuata veya şirketin ana sözleşme hükümlerine aykırı olması durumunda buna ek olarak "dürüstlük" kuralına aykırılığın tespit edilmesi halinde iptal davası açılacağı bilinmektedir. Kanunda öngörülen hallerden birinin varlığı halinde TTK'nın 446. maddesinde sayılan kişiler (pay sahipleri, yönetim kurulu, yönetim kurulu üyeleri) şirket merkezinin bulunduğu yer asliye ticaret mahkemesinde 3 ay içinde iptal davası açma hakkına sahiptir. TTK'nın 445.maddesinde sayılan sınırlı haller: Kanun hükümlerine aykırı olması hali, ortaklık esas sözleşmesi hükümlerine aykırı olması hali ve özellikle dürüstlük kuralına aykırı olması hali şeklindedir.

\footnotetext{
${ }^{3}$ 11. Hukuk Dairesinin 07.02.1984 tarih 1984/252 E. 594 K sayılı kararında özetle "... Oluşmayan ve henüz ortada mevcut olmayan bir genel kurul kararı aleyhine de iptal davası açılması ise yasal olarak mümkün değildir" hükmüyle Yargıtay genel kurul kararlarının iptal davasına konu edilebilmesi için ilk şart olarak geçerli bir genel kurul kararının varlığını arar". Denilerek hükme konu edilmiştir. Yargıtay 11. HD.'nin 28.5.1986 tarihli, 1986/1503 E. Ve 1986/3243 K. sayılı kararında da alınmış geçerli bir karar bulunmaması karşısında davanın kabulü halinde, kararın iptaline değil, talebin içinde mündemiç bulunan, kararın geçersizliğinin tespitine karar verilmek gerektiği" hükme konu edilmiştir.
} 
Buna göre alınan bir yönetici şirket genel kurul kararı yukarıda sayılan hukuki durumlardan birine aykırı olursa TTK'nın 446. maddesine göre pay sahipleri', Yönetim Kurulu ve Yönetim Kurulu üyeleri iptal davası açma hakkına sahiptir.

TTK'nın 445. maddesinde düzenlenen iptal sebeplerinden ilki genel kurul kararlarının kanun hükümlerine aykırı olması halidir. Kuşkusuz buradaki kanun hükümlerine aykırılıkla kast edilen sadece TTK hükümlerine aykırılık değildir (Poroy vd., 2019: 601; Kırca vd., 2017: 64; Bahtiyar, 2020: 205; Arslanlı, 1960: 79; Kayar, 2018: 433; Şener, 2011: 536-537; Türk, 2019: 94). Dolayısıyla yokluk ve butlan halleri hariç olmak üzere herhangi bir kanun hükmüne aykırılık sebebiyle iptal davası açılabilir. Kâr payı dağıtımına ilişkin bir önceki bölümde incelemiş bulunduğumuz TTK'nın özellikle 507, 508, 509 ve 519. maddelerine aykırı alınan kararlar bu kapsamda değerlendirildiğinde iptal davasının konusunu oluşturabilir.

TTK'nın 445. maddesinde düzenlenen iptal sebeplerinden ikincisi ise genel kurul kararlarının ortaklık esas sözleşmesi hükümlerine aykırı olması halidir. Pek tabi bu durumun gerçekleşebilmesi için ilk şart karar aykırılık oluşturduğu ön görülen esas sözleşme hükmünün hukuken geçerli olması gereklidir (Poroy vd., 2019: 602; Moroğlu, 2014: 231; Nomer, 2008: 143144).Buna ek olarak TTK'nın kâr payı dağıtımına ilişkin 523, 508 ve 507/2 hükümlerinde düzenlenen şartlara aykırı alınan kararlar bu yönden iptale konu edilebilir.

TTK'nın 445. maddesinde düzenlenen iptal sebeplerinden üçüncüsü ve sonuncusu ise dürüstlük kuralına aykırılıktır. Herkesin haklarını kullanırken ve borçlarını yerine getirirken dürüstlük kurallarına uymak zorunda olduğunu düzenleyen ve bir hakkın açıkça kötüye kullanılmasını hukuk düzeninin koruyamayacağını belirten Türk Medeni Kanunu'nun 2.maddesine aykırı olduğu iddia edilen genel kurul kararlarına karşı iptal davası açılabilir. Bu yönden hareketle esasen kanunlara veya esas sözleşmeye aykırılık teşkil etmese de dürüstlük kuralına aykırı olarak gerçekleştirilen kâr payı dağıtımının iptal davasının konusu olabileceği söylenebilir.

Uygulamada karşılaşılan somut olayın varlığına göre kâr payı dağıtımına ilişkin alınan genel kurul kararlarının butlanı söz konusu olabilir. Butlan halinde hukuki işlemin kurucu unsurlarının tam olması sebebiyle işlem kurulmuştur ancak hukuk işlemin geçerlilik unsurlarının tam olmaması sebebiyle baştan itibaren hüküm ve sonuç doğurmamaktadır. TTK'nın 447. maddesinde hangi koşul ve hallerde genel kurulda alınan kararların butlan sayılacağı düzenlenmiştir. Buna göre:

“Genel kurulun, özellikle;

a) Pay sahibinin, genel kurula katılma, asgari oy, dava ve kanundan kaynaklanan vazgeçilemez nitelikteki haklarını sınırlandıran veya ortadan kaldıran,

\footnotetext{
${ }^{4}$ TTK md 446' da "Toplantıda hazır bulunup da karara olumsuz oy veren ve bu muhalefetini tutanağa geçirten, toplantıda hazır bulunsun veya bulunmasın, olumsuz oy kullanmış olsun ya da olmasın; çağrının usulüne göre yapılmadığını, gündemin gereği gibi ilan edilmediğini, genel kurula katılma yetkisi bulunmayan kişilerin veya temsilcilerinin toplantıya katılıp oy kullandıklarını, genel kurula katılmasına ve oy kullanmasına haksız olarak izin verilmediğini ve yukarıda sayılan aykırılıkların genel kurul kararının alınmasında etkili olduğunu ileri süren pay sahipleri, “ denilerek iptal davasının açılması yönünden pay sahipleri 2 ye ayrılmıştır. İlk hak sadece toplantıya katılan pay sahiplerine tanınmıştır. Toplantıda hazır bulunan pay sahiplerinin genel kurul kararına ilişkin iptal davası yoluna başvurabilmek için genel kurul kararına karşı olumsuz oy vermiş olmaları ve de olumsuz oy vermelerine ilişkin muhalefet beyanlarını tutanağa geçirtmeleri zorunludur. 2. hak ise tüm pay sahiplerine tanınmış olan hakkı konu alır. Buna göre genel kurul toplantısında yapılan oylamada olumsuz oy kullanmış olsun ya da olmasın hatta toplantıda hazır bulunup bulunmadığına bakılmaksızın her pay sahibi TTK 445’ de sınırlı sayılı olarak sayılmış hukuki durumlar yönünden iptal davası açma hakkına sahiptir." Pay sahibi gerçek kişi ise iptal davasını kendisi; tüzel kişi ise yasal temsilcileri tarafından açılabilir. Bu kişilerin ortakları ya da genel kurula gönderdiği temsilcisi dava açma hakkına sahip değildir. Daha fazla bilgi için bkz: Poroy, R., Tekinalp, Ü. ve Çamoğlu, E. (2019). Ortaklıklar Hukuku - I (14. b., Cilt 1). İstanbul: Vedat Kitapevi, s.607-610.
} 
b) Pay sahibinin bilgi alma, inceleme ve denetleme haklarını, kanunen izin verilen ölçü dışında sinurlandıran,

c) Anonim şirketin temel yapısını bozan veya sermayenin korunması hükümlerine aykırı olan, kararları batıldır" denilmiştir.

TTK madde 447 hükmünde genel kurul kararlarının butlanı genel kurul kararlarının iptalinden ayrı bir şekilde düzenlemiştir. Madde içerisinde butlan oluşturacak sebeplerin önemli bulunanları sayılmış ve fakat butlanın tanımı ne 447.madde özelinde ne de TTK'nın diğer hükümlerinde butlanın tanımı yapılmamıştır. Ancak burada özellikle 447. Maddede sayılan haller sınırlı sayı (numerus clausus) özelliği taşımadığını belirtmek gerekmektedir. Kanun koyucu hükümde butlan sebebi oluşturabilecek temel sebepleri belirtmiştir. Dolayısıyla butlan hallerini sadece hükümde sayılı sınırlı haller olarak değerlendirmemek gerekir. Bu kapsamda değerlendirildiğinde kâr payı dağıtımına ilişkin olarak alınan genel kurul kararı konusu bakımından, kamu düzenine, emredici hükümlere, ahlâk ve adaba, kişilik haklarına aykırı veya konusu bakımından imkânsız ise, geçersizdir (Pulaşlı, 2013: 1-2).

Bu nitelikteki kâr payı dağıtımına ilişkin genel kurul kararlarının batıl olduğu iddiasıyla hukuki menfaati bulunan herkes iptal davasında belirlenen 3 aylık sürenin aksine herhangi bir süreyle sınırlandırılmadan tespit davası açabilir (Eren, 2013; Alper, 2012: 35).

Yapılan açıklamalar doğrultusunda şirketlerde kar payı dağıtımına ilişkin esaslar ve uygulamada çıkabilecek olan sorunlar TTK'da ilgili maddeleri çerçevesinde detaylandırılarak açıklanmaktadır. Çalışmanın bundan sonraki kısmında özellikle içinde bulunduğumuz süreç gibi salgın dönemlerindeki belirsizliklerin şirketlerin kar payı dağıtımına olan etkileri bağlamında açılamalara yer verilmektedir.

\section{YENİ KORONAVIRÜS (COVID-19) SALGIN DÖNEMINDE KAR PAYI DAĞITIMI}

Bilindiği gibi tüm dünyada, antik çağlardan günümüze kadar birçok salgına rastlanmaktadır. Yaşanan salgınların dünyanın büyük bir bölümünün hem ekonomik hem de toplumsal düzeyde geniş çaplı olumsuz etkileri meydana gelmiştir. Günümüzde, yeni bir koronavirüsün bir sonucu olarak ortaya çıkan salgınının tespit edilmesi ile tüm dünyada yeni bir süreç başlamıştır. Salgın ile mücadele noktasında ülkeler seviyesinde alınan önlemler dünya çapında ekonomik faaliyetleri olumsuz etkilemiş ve bu faaliyetlerin birer sonucu olarak ifade edilen finansal raporlar üzerindeki etkileri de olumsuz bir şekilde ortaya çıkmıştır. Belirsizliğin olduğu anda muhasebenin temel kavramlarından biri olan işletmenin sürekliliği kavramı açısından endişeler de ortaya çıkmaya başlamıştır (El-MousawiveKanso, 2020).

Bununla birlikte tüm dünyadaki ekonomik etkilerinin henüz net olarak belirlenemediği koronavirüs salgınının birçok şirketin operasyonları ve gelir döngüleri üzerinde son üç ayda çok ciddi olumsuz etkiler yarattı̆̆ bilinmektedir. Salgın sürecinde hemen hemen her sektördeki işletmelerde talep düşüklüğü ve borç - alacak dengesinin normal piyasa koşullarına göre sağlanamadığı da bilinmektedir. Özellikler işletmelerdeki başta tedarik zinciri yönetimi olmak üzere nakit yönetimindeki temel sorunlar şirketlerin, gelir döngüsüyle ilgili varlıklarının raporlama tarihinde bu faktörleri yansıtacak şekilde uygun bir şekilde ölçülüp ölçülmediğini değerlendirmesini zorunlu hale getirmektedir (KPMG, 2020). Bu noktada işletmenin başta kazanç yönetimi politikası olmak üzere mevcut salgın dönemindeki karını ve kar dağıtım politikalarını da gözden geçirmesi gerekmektedir (https://www.grantthornton.global/globalassets).

Benzer durumu finansal kriz dönemlerinde görmek de mümkündür. Özellikle ekonomik belirsizliğin ve dolayısıyla da riskin yüksek olduğu kriz dönemlerinde ya da krize neden olabilecek içinde bulunduğumuz süreç gibi salgın dönemlerinde de şirketler açısından kar 
dağıtımı ve karın yönetilmesi sorunu normal ekonomik koşullarda alınan kararlardan çok farklı şekillerde ortaya çıkmakta ve işletme ile ilgili tüm paydaşlar açısından dengeyi gözeterek stratejik bir karar alımı yapılmasını zorunlu kılmaktadır (Kowalska-MusiałveWydymus, 2014). Bu önermeyi destekler nitelikte Aleknevičienèvd.'nin (2003) araştırması gösterilebilir. Normal piyasa koşullarında bir şirkette alınan herhangi bir finansal karar - yatırım, karın dağıtımı, sermaye artışı ya da azalışı vb. - yatırımcıların alternatif yatırım olasılıklarından etkilenmekle kalmamakta aynı zamanda tüm paydaşların ihtiyaçlarını da karşılamaya dönük bir şekilde açıklanabilmektedir. Bu durum hem mevcut hem de potansiyel yatırıcımlar açısından şirkete yatırmış oldukları ya da yatıracağı paranın geri alınması ve bu yatırımın yüksek seviyede kazanç sağlaması ile birlikte değerlendirilmektedir. Bu noktada da yatırımın riski ile olan ilişkisi incelenmektedir (Aleknevičienė vd., 2006: 18). Ancak kriz dönemlerinde kar dağıtımına ilişkin karar daha stratejik bir öneme sahip olmakta ve net finansal sonuç olarak karşımıza net kar, dağıtıma tabi olan kar rakamını da ifade ettiğinden (Kowalska-Musiał and Wydymus, 2014) tüm paydaşların çıkarları doğrultusunda bir kar dağıtım stratejisinin gözetilmesini zorunlu hale getirmektedir (Petrova ve Beztsenny, 2016). Bu da özellikle bu dönemlerde net karın dağıtımının başta yasal olmak üzere birçok düzenlemede yer almasını açıklamaktadır.

Yeni koronavirüs salgın döneminde de yaşanılan belirsizlik ortamının şirketler üzerindeki olası etkilerini azaltmak amacıyla ülkemizde de bir düzenleme yapılmıştır. Bir sonraki başlık altında yapılan yasal düzenlemeye ve mevcut kar dağıtım süreçlerine olan etkilerine ilişkin değerlendirmeleri bulmak mümkündür.

\section{6102 SAYILI TÜRK TICARET KANUNU GEÇİİ MADDE 13 İLE GETİRILEN KAR PAYI DAĞITIM SINIRLAMASI VE UYGULAMASI}

17/04/2020 tarihli ve 7244 Sayılı Yeni Koronavirüs (Covıd-19) Salgınının Ekonomik Ve Sosyal Hayata Etkilerinin Azaltılması Hakkında Kanun İle Bazı Kanunlarda Değişiklik Yapılmasına Dair Kanun ile 6102 sayılı Türk Ticaret Kanunu'na eklenen Geçici 13'üncü madde eklenmiştir. 7244 Sayılı Kanunun gerekçesi "ekonomik faaliyetlerin azalması ve piyasalardaki belirsizlik ortamının toplum sağhlğ̆ ve ekonomi üzerindeki etkilerinin ölçülemediği bu nedenle de ihtiyatlllık politikası gereğ $i$ olarak, şirket nakit kâr dă̆ıtımı yapılması suretiyle azaltılmaması, şirketlerin mevcut özkaynak yapılarının korunması ve ilave finansman ihtiyacının doğmaması amactyla Geçici 13. madde ile 30.09.2020 tarihine kadar yapılacak kâr dağıtımına ilişkin düzenleme getirmek" olarak açıklanmaktadır.

Ticaret Bakanlığı tarafından söz konusu geçici maddenin uygulanmasına ilişkin usul ve esaslar hakkında açıklamalarda bulunmak amacıyla bir tebliğ hazırlanmış ve 17.05.2020 tarihli 31130 sayılı Resmi Gazetede 6102 Sayılı Türk Ticaret Kanunu'nun Geçici 13'üncü Maddesinin Uygulanmasına İlişkin Usul ve Esaslar Hakkında Tebliğ yayınlanmıştır. Bu tebliğ kapsamında kâr payının hesaplanmasında; finansal tabloların Kamu Gözetimi Muhasebe ve Denetim Standartları Kurumu tarafindan belirlenen standartlara uygun hazırlamak zorunda olanlar tarafindan Kanunun 88 inci maddesine göre hazırlanan, bunlar dişında kalanlar tarafından ise 4/1/1961 tarihli ve 213 sayılı Vergi Usul Kanununa göre hazırlanan finansal tablolar esas alınarak hesaplanacağına ilişkin açılamalar yer almaktadır. Yapılan bu kar payı dağıtımında öngörülen kar payı tutarı 4/1/1961 tarihli ve 213 sayılı Vergi Usul Kanunu'na göre tutulan kayıtlarda bulunan kâr dağıtımına konu kaynakların toplam tutarını aşamayacağı da ifade edilmektedir.

İlgili tebliğde 1.maddesindedevlet, il özel idaresi, belediye, köy ile diğer kamu tüzel kişilerinin ve sermayesinin yüzde ellisinden fazlası kamuya ait fonların ve doğrudan veya dolaylı olarak sermayesinin yüzde ellisinden fazlasına sahip olan şirketlerin yani 233 Sayıl Kamu İktisadi Teşebbüsleri Hakkında Kanun Hükmünde Kararname'nin 2. maddesinin 5. fikrasında belirtilen bağh ortaklıklar kapsam dışında bırakılmıştır. 
İlgili tebliğin 4. Maddesinde ise kar payı ve kar payı avansı dağıtımına ilişkin esaslar aşağıdaki gibi açıklanmaktadır:

Madde 4 (l) Sermaye şirketlerinde Kanunun geçici 13'üncü maddesinin yürürlüğe girdiği 17/4/2020 tarihinden 30/9/2020 tarihine kadar 2019 yılı net dönem kârının yalnızca yüzde yirmi beşine kadarının nakden dağıtımına karar verilebilir, geçmiş yıl kârları ve serbest yedek akçeler dă̆ıtıma konu edilemez. Bu sinırlama, Kanunun 462'nci maddesi uyarınca iç kaynaklardan yapılacak sermaye artırımında uygulanmayacaktır.

Bu hüküm ile ilk olarak TTK'nın 509/2 “kâr payı ancak net dönem kârından ve serbest yedek akçelerden dağıtılabilir" hükmünde düzenlenmiş bulunan serbest yedek akçelerden karın dağıtılması durumu ortadan kalkmıştır. İkinci olarak ise, TTK'nın 519/1'de düzenlenmiş olan kanuni yedek akçeyi ayırdıktan sonra ve şayet düzenlenmiş ise ana sözleşme ve genel kurul kararı ile ayrılan serbest yedek akçeler ayrıldıktan karın nasıl dağıtılacağı genel kurulun irade serbestisine tanınmışken; ilgili hüküm ile bu duruma da bir sınırlama getirilmiştir.

İlgili tebliğde Madde 4 kapsamında sermaye şirketlerine genel kurul tarafından 30/9/2020 tarihi sonuna kadar yönetim organına kâr payı avansı dağıtımı yetkisi verilemeyeceği düzenlenmiş ve ancak Kanunun geçici 13'üncü maddesinin yürürlüğe girmesinden önce genel kurulca kâr payı dağıtımı kararı alınmasına rağmen henüz pay sahiplerine ödeme yapılmamışsa veya kısmi ödeme yapılmışsa ise, 2019 yılı net dönem kârının yalnızca yüzde yirmi beşine kadarının nakden dağıtımına karar verilebileceğine ilişkin olan sınırı aşan kısma dair ödemeler ile hesap döneminde zarar edilmiş olmasına karşın serbest yedek akçelerden dağıtım kararı alınmışsa henüz ödenmemiş kısma ilişkin tüm ödemeler 30 Eylül 2020 tarihine kadar erteleneceği düzenlenmiş ve ertelenen işbu ödemelere ilişkin olarak faiz tahakkuk ettirilemeyeceği hüküm altına alınmıştır.

Tebliğin 5. maddesinde kar payı dağıtımına ilişkin istisnalar açıklanmıştır. Bu durum dahilinde tebliğin 4. Maddesinde düzenlenen sınırlamadan muaf tutulan gerçek ve tüzel kişiler aşağıda yer almaktadır:

1) 28/3/2002 tarihli ve 4749 sayılı Kamu Finansmanı ve Borç Yönetiminin Düzenlenmesi Hakkında Kanunun geçici 20'nci maddesi ve ilgili Kararlar uyarmca Hazine destekli kredi kefaleti kullanan ve halen kapanmamış kredi borç bakiyesi bulunanlar hariç, 120.000 Türk Lirası ve altında kâr payı dağıtımı kararı alınan şirketler,

2) 25/8/1999 tarihli ve 4447 sayılı İssizlik Sigortası Kanununun ek-2'nci ve geçici 23'üncü maddesi uyarınca yeni koronavirüs (Covid-19) kaynaklı zorlayıcı sebep gerekçesiyle kısa çalışma ödeneğinden ve/veya ücretsiz izne ayrllanlardan 4447 sayılı Kanunun geçici 24'üncü maddesi uyarınca nakdi ücret desteğinden yararlandırılanlarn istihdam edenler

3) Pay sahiplerince, dağıtımına karar verilen kâr payının yarısından fazlasının, Kanun hükümleri çerçevesinde başka bir sermaye şirketine olan sermaye taahhüt borcunun nakden ve defaten ifasinda kullanılması şartıyla, kâr payı dağıtımı kararı alınan şirketler,

4) Pay sahiplerince, dağıtımına karar verilen kâr payının, imzalanan kredi sözleşmeleri veya proje finansman sözleşmeleri kapsamında 4'üncü maddenin birinci fikrasında belirtilen sürenin sonuna kadar muaccel hale gelen yükümlülüklerin ifasında nakden kullanılması şartıyla, kâr payı dağıtımı kararı alınan şirketlerdir.

İlgili kişilerin kâr payı dağıtımlarının genel kurulda görüşülebilmesi için Bakanlıktan uygun görüş alınmasının zorunlu olduğu tebliğde ayrıca ifade edilmektedir. Bu durum kapsamında şirketlerin kar payı dağıtımlarının genel kurulda görüşülebilmesi için ilk olarak Bakanlıktan uygun görüş alınması zorunludur. Bakanlığa yapılacak olan başvurularda genel kurul 
yapılmasına ilişkin yönetim organı kararının noter onaylı örneği, şirketin hesap dönemine ilişkin finansal durum tablosu ile kâr veya zarar tablosuna ek olarak aşağıdaki belgeler ile birlikte sunulmak durumundadır:

a) 28/3/2002 tarihli ve 4749 sayılı Kamu Finansmanı ve Borç Yönetiminin Düzenlenmesi Hakkında Kanunun geçici 20'nci maddesi ve ilgili Kararlar uyarmca Hazine destekli kredi kefaleti kullanan ve halen kapanmamış kredi borç bakiyesi bulunanlar hariç, 120.000 Türk Lirası ve altında kâr payı dă̆ıtımı kararı alınan şirketler ile 25/8/1999 tarihli ve 4447 sayıll İsssizlik Sigortası Kanununun ek-2'nci ve geçici 23'üncü maddesi uyarınca yeni koronavirüs (Covid-19) kaynaklı zorlayıcı sebep gerekçesiyle kısa çalışma ödeneğinden velveya ücretsiz izne ayrllanlardan 4447 sayıl Kanunun geçici 24'üncü maddesi uyarnnca nakdi ücret desteğinden yararlandırlanları istihdam edenler anulan bentte belirtilen desteklerden yararlamılmadığına ilişkin ilgili kurumlardan kanıtlayıcı belge almak durumundadır.

b) Pay sahiplerince, dağıtımına karar verilen kâr payının yarısından fazlasının, Kanun hükümleri çerçevesinde başka bir sermaye şirketine olan sermaye taahhüt borcunun nakden ve defaten ifasında kullanılması şartıyla, kâr payı dağıtımı kararı alınan şirketler dă̆ıtılacak kâr payının yarısından fazlasını alma hakk olanları başka bir sermaye şirketine olan sermaye taahhüt yükümlülü̈̆̈̈nü kanıtlayacak belge almak durumundadır.

c) Pay sahiplerince, dağıtımına karar verilen kâr payının, imzalanan kredi sözleşmeleri veya proje finansman sözleşmeleri kapsamında 4'üncü maddenin birinci fikrasında belirtilen sürenin sonuna kadar muaccel hale gelen yükümlülüklerin ifasında nakden kullanılması şartıyla, kâr payı dağıtımı kararı alınan şirketlerin kredi sözleşmeleri ve proje finansman sözleşmeleri kapsamında ifa yükümlülüklerini kanıtlayıcı belge almak durumundadir.

\section{SONUÇ VE DEĞERLENDİRME}

İşletmeler açısından önemli stratejik kararlardan biri olarak görülen kar payı dağıtımı ve net karın dağıtılacak olan kısmının belirlenmesi olgusu muhasebe başta olmak üzere birçok disiplin içerisinde sıklıkla yer alan konuların başında gelmektedir. Özellikle işletmedeki tüm ortakların çıkarları doğrultusunda bir kar payı dağıtım stratejisinin gözetilmesi ve ekonomik belirsizlik ortamında bu kararların alınmasına rehberlik sağlamak amacıyla birçok ülkede farklı yasal düzenlemelerin yapıldığı bilinmektedir. Bu kapsamda ülkeler seviyesindeki yürürlükte olan yasal mevzuatlarda sürecin işletmeler açısından hem raporlanması hem de dağıtılmasına ilişkin usul ve esasları belirlemektedir. Bu da işletmeler seviyesinde gerçekleştirilen ve karar alımında önemli bir yer tutan kar payı dağıtımına ilişkin finansal bilginin hangi miktarlarda dağıtılacağını ve nasıl raporlanacağını belirlemektedir.

Bununla birlikte özellikle finansal kriz veya içinde bulunduğumuz yeni Koronavirüs (Covid 19) salgin süreci gibi ekonomik etkiler başta olmak üzere birden fazla boyutta etkileri olan kriz dönemlerinde ve sonrasında kâr payı dağıtımının nasıl olması gerektiği özellikle salgının toplumsal ve ekonomik boyuttaki etkilerini azaltmak ve işletmelerin sermaye yapılarını koruyarak sürekli olabilmeleri açısından son derece önem taşımaktadır. Bu bağlamda çalışmada öncelikle sermaye şirketlerindeki kâr payı dağıtımına ilişkin yasal mevzuat üzerinde durulmakta ardından özellikle salgın sürecinde bu salgının ekonomik ve sosyal hayata olan etkilerini azaltmak amacıyla 6102 Sayılı Türk Ticaret Kanunu'na eklenen geçici 13. Madde ile net dönem kar dağıtımının usul ve esaslarının değerlendirilmesi ve yeni belirlenen usul ve esasların uygulanmasında yaşanabilecek olası durumlar hakkında açılamalara yer verilmektedir.

TTK'ya hakim olan genel ilkelerden kurumsal yönetim ilkesi içerisinde değerlendirilmiş olan şirket menfaatleri doğrultusunda hareket edilmesi ve şirket menfaatine aykırı olmayacak şekilde genel kurul kararlarının alınması yer almakta olup bu konuda bir serbesti söz konusudur. Şirket menfaatlerinin korunması açısından TTK'nın gösterdiği bu önem şirketler hukuku özelinde 
borçlar sebebi ile şirket alacaklılarının sadece şirket malvarlığına başvurabilmelerinin de bir sonucu olmaktadır. Geçici 13. Madde düzenlemesi ile şirket organlarının kar payını dağıtması hususunun şirket menfaati ve borçlular aleyhine kullanmalarının önüne geçilmek istenmiştir. Kanun koyucu TTK'nın kar payı dağıtımına ilişkin hükümlerine doğrudan bir müdahale gerçekleştirilmiş ve salgın nedeni ile kar payı dağıtımının olumsuz sonuç doğurabilecek ve kelebek etkisi yaratabilecek ekonomik dalgalanmanın önüne geçmeyi hedeflemiştir. Ancak hükümlerin uygulanmaması halinde şirketlerin karşılacağı yaptırımın hangi hususlarda olacağının tebliğ içerisinde yer almaması kanımızca bir eksiklik olarak değerlendirilmektedir.

\section{KAYNAKÇA}

6102 Sayılı TTK, 14. 02. 2011 Tarih ve 27846 Sayılı Resmi Gazete.

7244 Sayılı Yeni Koronavirüs (Covıd-19) Salgınının Ekonomik Ve Sosyal Hayata Etkilerinin Azaltılması Hakkında Kanun İle Bazı Kanunlarda Değişiklik Yapılmasına Dair Kanun, 17.04.2020 Tarih ve 31102 Sayılı Resmi Gazete.

233 Sayılı Kamu İktisadi Teşebbüsleri Hakkında Kanun Hükmünde Kararname, 18.06.1984 Tarih ve 18435 Sayılı Resmi Gazete.

6102 Sayılı TTK' nın Geçici 13 Üncü Maddesinin Uygulanmasına İlişkin Usul Ve Esaslar Hakkında Tebliğ, 17.05.2020 Tarih ve 31130 Sayılı Resmi Gazete.

Aleknevičienė, V., Jatkūnaitė, D. And Žaltauskienė, N. (2003). The Research of Dividend signaleffect in Lithuanianshare market. Organizacijųvadyba: Sisteminiaityrimai, (28), 7-19.

Aleknevičienè, V., Domeika, P., and Jatkūnaitè, D. (2006). The Development of Company Dividend Policy in Respect of Profit Distribution Priorities. Inžinerinėekonomika., 2006, Nr. 5 (50).

Alper, G. (2012). Türk Ticaret Kanunu Tasarısına Göre Anonim Şirketlerde Genel Kurul Kararlarının Hükümsüzlüğü. B. Tiryakioğlu ve G. Güngör içinde, Prof. Dr. Tuğrul Arat'a Armağan (s. 61-88). Ankara: Yetkin Yayınları.

Arslanl, H. (1960). Anonim Şirketler II-III - Anonim Şirketin Organizasyonu ve Tahviller (Cilt 2-3). İstanbul: Fakülteler Matbaası.

Bahtiyar, M. (2020). Ortaklıklar Hukuku (14. b.). İstanbul: Beta Yayınevi.

Eren, F. (2013). Borçlar Hukuku Genel Hükümler (14. b.). Ankara: Yetkin Yayınevi.

El-Mousawi, H. And Kanso, H. (2020). Impact of COVID-19 Outbreak on Financial Reporting in theLight of the International Financial Reporting Standards (IFRS) (An Empirical Study). Research in Economics and Management, 5 (2), 21-38.

Hendriksen, Eldon S. 1982. Accounting Theory, Fourth Edition, USA: Richard D. Irwin, Inc.

Kayar, İ. (2018). 6102 Sayılı Türk Ticaret Kanunu'na göre Ticaret Hukuku (5. b.). Ankara: Seçkin Yayınları.

Kayıhan, Ş. (2019). Şirketler Hukuku (3. b.). Ankara: Seçkin Yayınları.

Kırca, İ., Şehirali Çelik, F. H. ve Manavgat, Ç. (2017). Anonim Şirketler Hukuku - Genel Kurul Kararlarının Hükümsüzlüğü (Cilt 2). Ankara: Banka ve Ticaret Hukuku Araştırma Enstitüsü.

Kowalska-Musiał, M., \& Wydymus, Z. (2014). Zysk Netto Oraz Polityka Jego Podziału W Dobie Kryzysu Gospodarczego W Aspekcie Postrzegania Realizacji Nadrzędnego Celu Działalności Współczesnego Przedsiębiorstwa. Zeszyt Naukowy Wyższej Szkoły Zarządzania i Bankowości w Krakowie, (34), 49-71. 
Littleton, A.C. and V.K. Zimmerman. 1962. Accounting Theory: ContinuityandChange, USA: Prentice- HallInc., Englewood Cliffs N. J.

Moroğlu, E. (2014). Anonim Ortaklıkta Genel Kurul Kararlarının Hükümsüzlü̆̆̈̈ (7. b.). İstanbul: On İki Levha Yayıncilı.

Nomer, H. N. (2008). Kişi Birliklerinde Genel Kurul Kararlarının Geçersizliğine İlişkin Temel Esaslar. İstanbul: Beta Yaynevi.

Pasinetti, L. L. (1962). Rate of Profit and Income Distribution in Relation to the Rate of Economic Growth. The Review of Economic Studies, 29 (4), 267-279.

Petrova, Y. A., and Beztsenny, M. F. (2016). Specifics of Distribution of Profits in Joint - stock Companies. Ekonomicke Trendy, (4), 22-23.

Poroy, R., Tekinalp, Ü. ve Çamoğlu, E. (2019). Ortaklıklar Hukuku - I (14. b., Cilt 1). İstanbul: Vedat Kitabevi.

Pulaşlı, H. (2013). Anonim Şirket Genel Kurul Kararlarının Sakatlığı ve Müeyyidesi. Gazi Üniversitesi Hukuk Fakültesi Dergisi, 17 (1), 885-898.

Pulaşlı, H. (2020). Şirketler Hukuku Genel Esaslar (6. b.). Ankara: Adalet Yayınları.

Shabani, V., Mir Aghaei, S. M., and Shabani, V. (2014). Investigating the Relation Ship Between Earnings and Stock Prices in Companies Accepted in the Stock Exchange: A Case Study in Iran (2000-2010). European Online Journal of Natural and Social Sciences: Proceedings, 2 (3), 3102 .

Şener, O. H. (2011). Teorik ve Uygulamalı Ortaklıklar Hukuku (2. b.). Ankara: Seçkin Yayıncılık.

TMS 1- Finansal Tabloların Sunuluşu Standardı, https://kgk.gov.tr/Portalv2Uploads/files/Duyurular/v2/TMS/TMS\%201\%20Finansal\%20T ablolar\%C4\%B1n\%20Sunulu\%C5\%9Fu.pdf, (Erişim Tarihi: 10. 05. 2020)

Türk, M. C. (2019). Anonim Şirketlerde Genel Kurul Kararlarının İptali. Ankara: Adalet Yayınları.

Uçma, T. (2011). Muhasebenin Teorik Yapısı Genel Bir Bakış. Ankara: Gazi Kitabevi.

https://www.grantthornton.global/globalassets/1.-member-firms/global/insights/insightcontent-blocks-and-media/covid19-financial-reporting-and-disclosures/covid-19financial-reporting-and-disclosures.pdf, (Erişim Tarihi: 01. 06. 2020).

https://home.kpmg/xx/en/home/insights/2020/03/covid-19-revenue-cycle-07d.html, $\quad$ (Erişim Tarihi: 01. 06. 2020). 